1

2

\section{The role of elections as drivers of tropical deforestation}

\section{4}

5 Authors

6 Joeri Morpurgo* ${ }^{1}$, W. Daniel Kissling ${ }^{1}$, Peter Tyrrell ${ }^{2,3,4}$, Pablo J. Negret ${ }^{5,6}$, James R. Allan ${ }^{1}$

7

\section{Affiliations}

$9{ }^{1}$ Institute for Biodiversity and Ecosystem Dynamics (IBED), University of Amsterdam, P.O. Box 94240, $101090 \mathrm{GE}$, Amsterdam, The Netherlands

$11{ }^{2}$ South Rift Association of Landowners, P.O. Box 15289, Nairobi 00509, Kenya

$12{ }^{3}$ Department of Geography and Environmental Studies, University of Nairobi, Nairobi, Kenya
${ }^{4}$ Wildlife Conservation Research Unit, Oxford University

${ }^{5}$ The University of Queensland, School of Earth and Environmental Sciences, Qld 4072, Australia

${ }^{6}$ Centre for Biodiversity and Conservation Science, University of Queensland, Brisbane, QLD 4072, Australia.

* Correspondence to: Joeri Morpurgo. E-mail: joeri.morpurgo@gmail.com. Postal address: Environmental Biology Department, Institute of Environmental Sciences, CML, Leiden University, Leiden, The Netherlands. Phone number: +31681075924 
Abstract

Tropical forests support immense biodiversity and provide essential ecosystem services for billions of people. Despite this value, tropical deforestation continues at a high rate. Emerging evidence suggests that elections can play an important role in shaping deforestation, for instance by incentivising politicians to allow increased utilisation of tropical forests in return for political support and votes. Nevertheless, the role of elections as a driver of deforestation has not been comprehensively tested at broad geographic scales. Here, we created an annual database from 2001 to 2018 on political elections and forest loss for 55 tropical nations and modelled the effect of elections on deforestation. In total, 1.5 million $\mathrm{km}^{2}$ of forest was lost during this time period, and the rate of deforestation increased in $37(67 \%)$ of the analysed countries. Deforestation was significantly lower in years with presidential or lower chamber elections compared to non-election years, which is in contrast to previous local-scale studies. Moreover, deforestation was significantly higher in presidential or lower chamber elections that are competitive (i.e. when the opposition can participate in elections and has a legitimate chance to gain governmental power) compared to uncompetitive elections. Our results document a pervasive loss of tropical forests and suggest that competitive elections are potential drivers of deforestation. We recommend that organisations monitoring election transparency and fairness should also monitor environmental impacts such as forest loss, habitat destruction and resource exploitation. This would benefit the tracking of potential illegal vote buying with natural resources.

Keywords: biodiversity threat, forest loss, governance, habitat loss, policy, democracy 3 4

(1)




\section{Introduction}

Tropical forests contain Earth's richest biota and are the last refuges for many imperilled species (Gaston, 2000; Gibson et al., 2011). Tropical forests also provide globally important ecosystem services such as carbon sequestration and clean water provisioning (Foley et al., 2007). As many as 1.6 billion rural people live in close proximity to forests and may depend on forest resources for their livelihoods (Angelsen et al., 2014; Joshi and Joshi, 2019; Rudow et al., 2013). It is therefore concerning that tropical deforestation has reached critically high levels in the last few decades, with as much as $79,000 \mathrm{~km}^{2}$ - an area similar in size to Austria - being cleared every year (Austin et al., 2017). Understanding what drives tropical deforestation is thus crucial for implementing policy and conservation actions to ensure forest preservation.

The most prevalent direct causes of tropical deforestation include commercial logging (Curtis et al., 2018; Hosonuma et al., 2012), subsistence logging (e.g. for firewood; Heltberg et al., 2000; Hosonuma et al., 2012), conversion of forests to agricultural lands (e.g. for oil palm plantations or cropping; Hosonuma et al., 2012; Koh and Wilcove, 2008; Laurance et al., 2014), and wildfires which are often started by subsistence slash and burn agriculture (Laurance et al., 2002). There is good evidence that these drivers of deforestation increase when certain enabling factors are at play. One of these factors is corruption, which has been associated with higher rates of deforestation (Burgess et al., 2012; Smith et al., 2003; Wright et al., 2007). Another factor is the Gross Domestic Product (GDP) of a country, with higher deforestation occurring in countries with lower GDP (Ewers, 2006). Deforestation also tends to be higher in countries with higher human population densities (Sandker et al., 2017). Interestingly, factors such as a free media are associated with less deforestation, perhaps countering the effects of corruption (Bertot et al., 2010; Kolstad and Wiig, 2009). Other factors that potentially influence deforestation (e.g. armed conflicts, illegal crop production, or political elections and election cycles) have been less studied, even though there is growing evidence that they could drive deforestation trends in the tropics (Dávalos et al., 2016; Landholm et al., 2019; Negret et al., 2019).

Recent evidence suggests that elections could be key drivers of deforestation (List and Sturm, 2006; Pailler, 2018; Rodrigues-Filho et al., 2015). For example, a local scale study in Brazil found that municipal level deforestation was $8-10 \%$ higher in years when there was a municipal election (Pailler, 2018). Moreover, a similar increase in deforestation was also found during the national elections in Brazil (Rodrigues-Filho et al., 2015). During gubernational elections, in the United States of America, governors are more likely to advance or retract environmental policy based on the preference of the voters of their state. For instance, in "green" states environmental policy is more 
likely to advance during the election period, whereas in "brown" states it is more likely to retract (List and Sturm, 2006). A recent study investigating the economic and political incentives of deforestation in Indonesia found that deforestation substantially increases before a mayoral election, suggesting that political incentives reinforce tropical deforestation (Cisneros et al., 2021). This suggests that elections can influence deforestation, but broad generalizations should be made cautiously given the limited geographical scope, or the limited quality and resolution of deforestation data used in these studies so far.

Elections could increase deforestation via multiple mechanisms. Elections are power struggles where politicians aim to gain an advantage over opponents. These advantages can be achieved through popular policies and by creating economic opportunities (Akhmedov and Zhuravskaya, 2003; Drazen and Eslava, 2010; Nordhaus, 1975). For example, politicians might gift or promise forested land for exploitation to win favour with powerful potential supporters, or with businesses such as developers and loggers. A real world example occurred in Uganda in 2011, where the incumbent government promised forests to win community support (Médard and Golaz, 2013). A similar example is the 2018 Brazilian presidential elections which caused a spike in deforestation due to candidates promising the dismantling of environmental laws (Abessa et al., 2019). Leading up to elections, governments may be so focussed on electioneering that diverts their attention from environmental protection and turn a blind-eye to people utilising forest resources, allowing them to harvest unsustainably or to settle on protected forested land (Negret et al., 2017). Most countries have strong laws against winning political favour through financial bribery. However, environmental protection laws are usually less rigorously monitored or upheld than financial laws, making winning support by giving away land and forest resources an attractive alternative to money (Ohman, 2013). There are many mechanisms for elections to drive deforestation but the effect of elections on deforestation remains under-investigated, especially at broad geographic extents.

Here, we analyse the effect of elections as drivers of deforestation at a pantropical scale. We focus on the tropics because the mechanisms and drivers of deforestation are fairly distinct from the higher latitude forests in the temperate, boreal and taiga zone (Curtis et al., 2018). To assess the drivers of tropical deforestation, we first explored the directionality and shape of temporal trends in deforestation within 55 pantropical countries from 2001 to 2018 using remotely-sensed global forest loss data (Hansen et al., 2013). High-resolution (30 $\times 30$ metre) year-by-year global forest loss data is now available from 2000 to 2018 (Hansen et al., 2013), providing new opportunities to study the effect of elections on deforestation more accurately and at unprecedented spatial extents. 
We created an annual database over this time period covering the year in which national elections took place and which type of election it was (presidential, lower chamber, and upper chamber elections). We further extracted additional information on governance (e.g. competitiveness, media integrity, corruption control) and human population density. We used a Hierarchical generalized additive model (HGAM; Pedersen 2019) to assess the effect of election and the governance variables on the proportional deforestation of countries relative to their forest cover in the year 2000. This HGAM approach allows the modelling of non-linear functional relationships between covariates and outcomes where the shape of the function itself varies between different grouping levels (e.g. countries). This technique allowed us to disaggregate the changes in forest loss in each country over time - which can be driven by various factors - from the election covariates. These analyses allowed us to (1) quantify the effect of presidential, lower chamber, and upper chamber elections on tropical deforestation rates compared to non-election years, and (2) to test whether the competitiveness of an election has an effect on deforestation.

\section{Methods}

\subsection{Data collection}

We developed an annual 2001-2018 database for 55 tropical-forest countries (Table A1; Figure A1) covering national and state-level deforestation, election dates, governance variables and human population density. The governance variables included competitiveness of elections, media integrity of a country, and control of corruption (Table 1). Human population density captured the number of residents per country area (Table 1 ).

We extracted annual forest loss data for each country for the years 2001-2018 using high resolution ( $30 \times 30$ metre) global maps of forest cover and forest loss (Hansen et al., 2013). Data were extracted and processed in the Google Earth Engine (https://earthengine.google.com), a cloud platform for earth-observation data analysis (Gorelick et al., 2017). We adapted code from Tracewski et al. (2016) to quantify forest loss per year and country, and make our code available via GitHub (https://github.com/JoeriMorpurgo/Elections2020). The Global Forest Change database defines forest as $>50 \%$ crown cover of trees taller than $5 \mathrm{~m}$ height. The presence of forest is given for each 30 $\times 30$ metre pixel using the year 2000 as a baseline. Forest loss is defined as the disappearance of a forest pixel in a given year ( $1=$ loss, $0=$ no loss). A given forest pixel can only be lost once (in years 2001-2018). We used the available data on forest cover (year 2000) and forest loss (years 20012018) to calculate the proportional loss (i.e. deforestation) over a given year within (sub)national boundaries relative to the forest cover in the year 2000 (see methodological example in Figure A1). 
152 period (Hansen et al., 2013) and because it is often due to plantation forests rather than natural 153 regrowth or restoration (Tropek et al., 2014). The Global Forest Change data is considered the most 154 accurate global deforestation data available. However, we acknowledge limitations such as the 155 inability to differentiate between forest and agro-forests, which have been discussed elsewhere 156 (Tropek et al., 2014, Allan et al. 2017).

We gathered data on when national level elections took place by examining each country's constitution, and cross-checking this with a number of election databases (see Table B2). In the few cases where we could not find a formal source we utilised Wikipedia ( $n=4,0.9 \%$ ), which is regarded as a credible source for election data (Brown, 2011). We collected information on three types of national elections: (i) Lower chamber elections, where the lower chamber holds the legislative power allowing them to create laws; (ii) Upper chamber elections, where the upper chamber reviews the legislative power; and (iii) Head-of-state or head-of-government elections (hereafter called 'presidential elections') depending on who holds the executive power to enforce the law and is elected. All countries analysed had a lower chamber and presidential elections. However, many countries did not have upper chamber elections (25 out of 55 countries, i.e. $45 \%$ ). Presidential and upper chamber election dates often occur in the same year as lower chamber elections $152 \%$ and $38 \%$ of the time, respectively). All election types were treated as a binary predictor variable $(1=$ year with election, $0=$ no election), i.e. either occurring in a given year or not.

We extracted governance information and human population density from various sources (for details see Table 1). Elections were scored as competitive (=1) when they are sufficiently free for the opposition to gain legislative or executive power with enough votes, and otherwise as noncompetitive $(=0)$ (see 'Competitive elections' in Table 1). Note that this variable does not capture whether parties have equal funding, media coverage or whether civil liberties are respected. Hence, competitive elections are not equal to free and fair elections (Skaaning et al., 2015). We further used an index from the World Bank which captures the control of corruption, which has been linked to both tropical deforestation and enhancing election cycles (Kaufmann et al., 2011; Pereira et al., 2009; Smith et al., 2003). We also extracted a variable which quantifies to what extent media are diverse and critical ('Media integrity' in Table 1), as this has been shown to counter the effects of election cycles (Akhmedov and Zhuravskaya, 2003; Tufis, 2019). Finally, we also accounted for human population density, since higher densities at a national level tend to increase deforestation (World bank, 2020). All predictor variables, included in the analysis, were compiled at national and annual scale. Four countries lacked data on 'Competitive elections', leading to exclusion in the Hierarchical 
Table 1. Summary of predictor variables which were included in Hierarchical Generalized Additive Models to explain proportional deforestation of a country relative to the forest cover in the year $\mathbf{2 0 0 0}$ (response variable). The predictor variables capture governance aspects (competitive elections, media integrity and control of corruption) and human population density.

Variable Definition and methods Reference \& source

Competitive Competitive elections (referred to as 'Competitive' in our

elections

Media integrity

Control of

corruption

Human

population

density

(2) members of the executive or legislative are only

constitutionally removed, (3) elections are held at a time

parties are not banned, and (5) voters experience little

systematic coercion in their electoral vote.

sphere.

range $-1.68-0.76$, created by modelling 50 variables on

elite and private interests. analysis) is a binary variable that quantifies whether elections

are sufficiently free for the opposition to gain legislative or

executive power (1) or not (0). This reflects whether the seats of

the executive and legislative body are filled by elections that are

characterized by uncertainty in terms of the final outcome. This

includes that (1) the legislature is only constitutionally dissolved,

consistent with constitutional requirements, (4) non-extremist

Media integrity measures to what extent media are diverse and

critical on governmental issues. It is a continuous composite

variable with a range $0.00-0.83$, based on five indicators: (1)

How often media are critical of the government, (2) how wide

the range of media perspectives is, $(3)$ if there is media bias

against government opposition, (4) whether media accepts

bribes to alter news coverage, and (5) to what extent criticism of

the government is common and normal in the mediated public

Control of corruption measures the perception of corruption by

public power for private gain. It is an continuous index with a

corruption. It intends to capture the extent to which public

power is exercised for private gain. This includes both petty and

grand forms of corruption, and the 'capture' of state assets by

Population density is defined as all residents of a given political

World bank, 2020

Tufis, 2019

Tufis, 2019

Kaufmann et al., 2011

of a country). Refugees who are not permanently settled are 


\subsection{Statistical analyses}

The statistical analysis aimed to assess (1) the directionality and shape of temporal trends in deforestation, (2) the effect of presidential, lower chamber, and upper chamber elections on deforestation, and (3) the effect of competitiveness of elections on deforestation trends.

First, we used a non-parametric Mann-Kendall test (Kendall, 1938; Mann, 1945) to test for monotonic trends (i.e. directionality) of deforestation over time for each country. This test is more robust to outliers, non-normality and temporally autocorrelated data than simple linear models and is widely used in time-series analysis (Yue et al., 2002).

Second, we used Hierarchical Generalized Additive Models (HGAM) (Lin and Zhang, 1999; Pedersen et al., 2019; Wood, 2017) to model non-linear trends in deforestation in relation to election type and competitiveness of elections. The flexible nature of HGAMs allows for modelling smooth patterns across space and over time, with the amount of smoothing controlled to prevent over-fitting (Wood 2017). The HGAM approach thus allows the modelling of non-linear functional relationships between covariates and outcomes where the shape of the function itself varies between different grouping levels. In our case, this grouping variable was the country level. This technique allowed us to disaggregate the changes in forest loss in each country over time - which can be driven by various factors - from the election covariates. Our models used a global smoother plus country-level smoothers with differing wiggliness (Pedersen et al., 2019).

We used three separate HGAMs to model each election type independently: a presidential model, a lower chamber model and an upper chamber model. The general mathematical formulation of the HGAMs was:

\section{$g$ (Deforestation)}

$$
\begin{aligned}
& =\text { Election }+(\text { Election } \times \text { Competitive })+f(\text { Pop density })+f(\text { Media integrity }) \\
& +f(\text { Corruption })+f_{\text {country }}(\text { Year })+\zeta_{\text {country }}+\epsilon
\end{aligned}
$$

Where $g$ (Deforestation) is the response variable defined as proportional deforestation of a country relative to the forest cover in the year 2000. The binary predictor variable Election is 1 when an election is being held in a given year, and 0 if not. The Election term differs among HGAMs because of the different election data (presidential, lower chamber or upper chamber). The binary predictor variable Competitive is 1 if the election setting is competitive, and 0 if it is not, and modelled as an interaction with the Election term (i.e. Election $\times$ Competitive). The predictors $f$ (Pop density ${ }_{i}$ ), $f\left(\right.$ Media integrity $\left._{i}\right)$ and $f\left(\right.$ Corruption $\left._{i}\right)$ are all modelled smooths allowing for non-linear relationships. All smooths used penalized thin plate regression splines (TPRS) (Wood, 2003). With these splines, the null space is also penalized slightly, and the whole term can therefore be shrunk to zero, effectively acting as a model fitting step (Wood, 2003). The additional advantage of the TPRS approach is that knot positions were selected automatically from the data, eliminating knot placement subjectivity. Random effects are described by $\zeta_{\text {country }}$, which accounts for country-level mean differences of deforestation at the intercept as suggested by Pedersen et al. (2019). The term $f_{\text {Country }}($ Year $)$ is a separate univariate smooth for each country to account for intergroup variability. We used a Gaussian process smooth to account for temporal autocorrelation (Wood, 2017). Finally, $\in$ describes the error that is not explained by the other terms. HGAMs were modelled 
232 using a beta regression logit link structure to account for the proportional nature of the response 233 variable which is bound between 0 and 1 , and overcomes limitations in other more commonly used distributions (Douma and Weedon, 2019). For each term the penalty controlling the degree of smoothing was selected using restricted maximum likelihood (REML; Wood 2017, p. 185)

The autocorrelation function of the residuals, concurvity and model residuals were visually inspected for all models, and no issues were identified. The supplementary material provides the autocorrelation function of the residuals (Figure B1), the concurvity (Figure C 1-3), and the model residuals (Figure D1).

\section{Results}

243

\subsection{Global deforestation trends from 2001 to 2018}

We found that 1.5 million $\mathrm{km}^{2}$ of tropical forest - an area similar in size to Mongolia - was lost between 2001 and 2018 in the 55 tropical countries analysed (Table 1A). The largest area of forest loss occurred in Brazil $\left(469.839 \mathrm{~km}^{2}\right)$, followed by Indonesia $\left(227.008 \mathrm{~km}^{2}\right)$ and the Democratic Republic of Congo (112.626 km ${ }^{2}$ ) (Figure $1 \mathrm{~A}$ ). On average, $0.52 \%$ of the world's tropical forests were lost each year from 2001 to 2018 (SD $=0.15 \%$, range $=0.35 \%-0.91 \%, n=55$ countries). The overall proportion of pantropical deforestation has increased during this time by $182 \%$, with 37 out of the 55 assessed countries (67\%) showing statistically significant increases (demonstrated by Mann Kendall tests showing statistically significant positive tau values at $p<0.05$ ) (Figure 1B). Only four countries 
A)

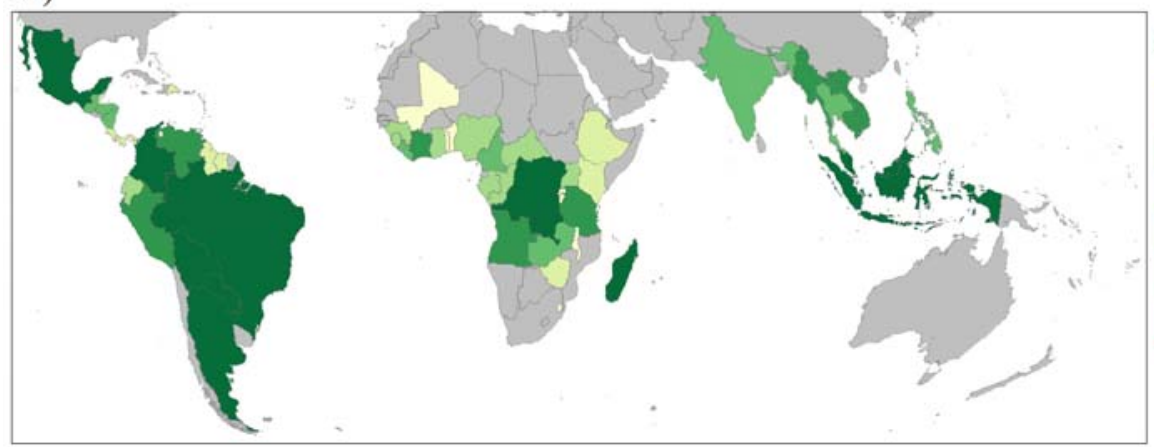

Deforestation $\left(\mathrm{km}^{2}\right)$

B)

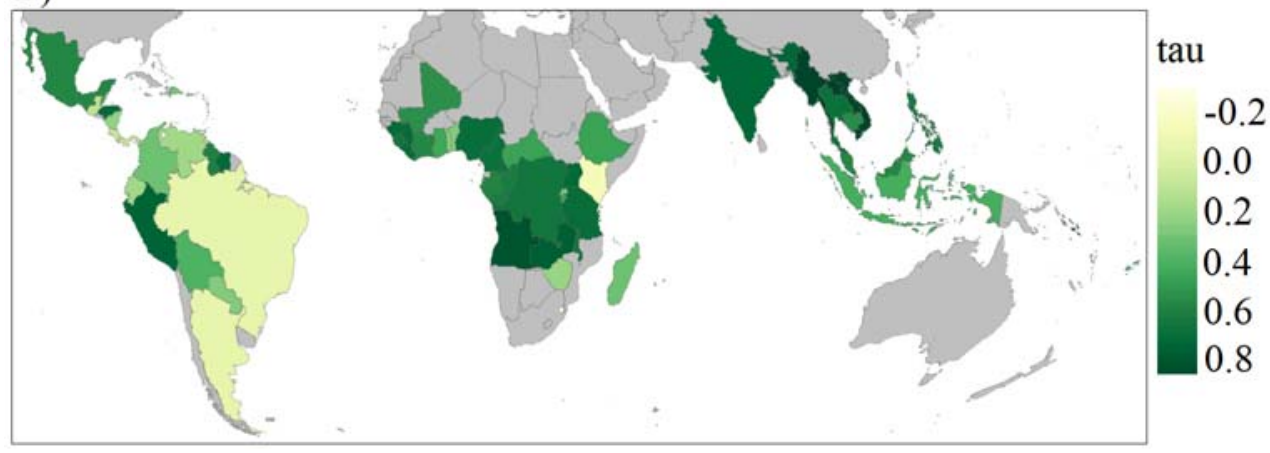

258 Figure 1. Deforestation in 55 tropical countries between 2001-2018. A) Total amount of deforestation (in $\mathrm{km}^{2}$ ) at a national scale from 2001-2018. B) Directionality and strength of national deforestation trends quantified as correlation coefficients (Tau values) from Mann Kendall tests. A total of 51 countries show an increase in the annual rate of deforestation (light green-green: positive Tau values) whereas four countries show a decrease (light yellow: negative Tau values). Annual forest loss data for each country were derived from high resolution (30 $\times 30$ metre) global maps of forest cover and forest loss (Hansen et al., 2013). 
The shapes of deforestation trends derived from the HGAMs varied considerably among countries $(n=51)$ (Figure 2A). In general, they followed five main typologies (Figure 2B-F): linearly increasing, linearly decreasing, curvilinearly increasing, curvilinearly decreasing and fluctuating. We visually inspected these deforestation trends for each country and found that the rate of deforestation increased in $36(71 \%)$ of the analysed countries $(n=51)$. Of those, 24 countries showed a linearly increasing deforestation trend (Figure $2 \mathrm{~B}$ ) and 12 countries an increasing curvilinear trend (Figure 2D). Two countries showed a linearly decreasing trend (Figure 2C) and five countries curvilinearly decreasing trend (Figure 2E). A total of 8 countries were classified as having fluctuating deforestation trends (Figure 2F).
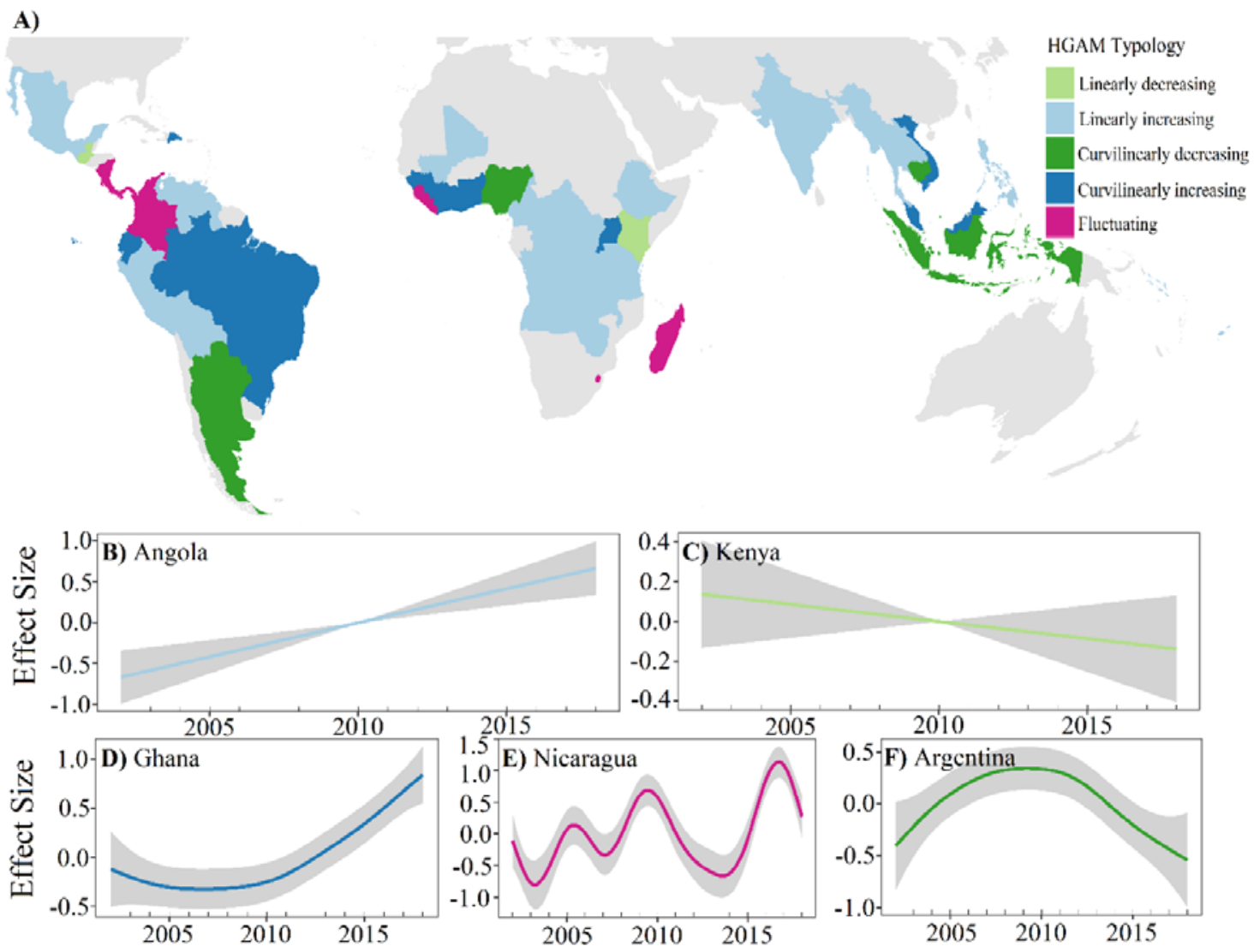

Figure 2. National deforestation trends between 2001-2018 across the tropics. A) Pantropical overview of main typologies of deforestation trends (linearly increasing, linearly decreasing, curvilinearly increasing, curvilinearly decreasing and fluctuating) as derived from Hierarchical Generalized Additive Models (HGAMs). Examples of trend typologies: B) linearly increasing (Angola), C) linearly decreasing (Kenya), D) curvilinearly increasing (Ghana), E) fluctuating (Nicaragua), and F) curvilinearly decreasing (Argentina).

\subsection{Election types and deforestation}

All three HGAMs had high explanatory power $\left(R^{2}>0.87\right.$, explained deviance $>90 \%$, see Table 2$)$ and show that tropical deforestation is lower in years when there is a presidential or lower chamber election, compared to years with no election (Figure 3A, B). This is demonstrated by the negative and statistically significant logit estimate for in the two HGAMs for presidential and lower chamber elections (Table 2). The logit estimate for the upper chamber HGAM also showed a negative sign but was statistically not significant (Table 2, Figure 3C). 
289

290

291

292

293

294

295

296

297

298

299

300

301

302

303

304

305

306

307

308

309

310

311

312

313

314

315

316

317

318

319

320

\subsection{Effect of competitiveness on deforestation}

Deforestation was significantly higher in competitive presidential and lower chamber election years, compared to non-competitive election years (Figure 4A, B). This is demonstrated in the positive and statistically significant interaction term Election $\times$ Competitive in the presidential and lower chamber HGAMs (Table 2). The upper chamber HGAM showed a negative interaction term Election $\times$ Competitive but this was not statistically significant (Table 2, Figure $4 \mathrm{C}$ ). None of the other predictors (human population density, media integrity, and control of corruption) showed a statistically significant effect on deforestation trends (Table 2). 
Table 2. Results of Hierarchical Generalized Additive Models (HGAMs) with a logit-link to explain the proportional deforestation of a country relative to the forest cover in the year $\mathbf{2 0 0 0}$ (response variable). Three different HGAMs were implemented depending on the specific election type (presidential, lower chamber, or upper chamber election). Binary predictor variables are shown with parametric coefficients (logit estimates) whereas continuous variables are represented with smooth terms. For details

of predictor variables see Table 1 . Country-level estimates ( $n=51$ countries) were excluded from this table. Statistically significant $p$-values ( $p<0.05$ ) are indicated in bold.

$$
\text { Presidential model Lower chamber model Upper chamber model }
$$

\begin{tabular}{|c|c|c|c|c|c|c|c|c|c|c|c|c|}
\hline Predictor & Estimate & Std. error & Z-value & $p$ & Estimate & Std. error & Z-value & $p$ & Estimate & Std. error & Z-value & $p$ \\
\hline Intercept & -5.47 & 0.10 & -57.10 & $<0.001$ & -5.47 & 0.10 & -56.90 & $<0.001$ & -5.52 & 0.14 & -40.34 & $<0.001$ \\
\hline \multicolumn{13}{|l|}{ Parametric coefficients } \\
\hline Election & -0.19 & 0.06 & -3.07 & 0.002 & -0.10 & 0.04 & -2.33 & 0.02 & -0.02 & 0.06 & -0.35 & 0.73 \\
\hline Election $\times$ Competitive & 0.16 & 0.07 & 2.30 & 0.02 & 0.13 & 0.06 & 2.26 & 0.02 & -0.01 & 0.07 & 0.09 & 0.93 \\
\hline Smooth term & & $e d f$ & $\mathrm{Chi}^{2}$ & $p$ & & $e d f$ & $\mathrm{Chi}^{2}$ & $p$ & & $e d f$ & $\mathrm{Chi}^{2}$ & $p$ \\
\hline$f$ (Population density) & & $<0.001$ & $<0.001$ & 0.79 & & $<0.001$ & $<0.001$ & 0.82 & & $<0.001$ & $<0.001$ & 0.36 \\
\hline$f$ (Media integrity) & & $<0.001$ & $<0.001$ & 0.41 & & $<0.001$ & $<0.001$ & 0.37 & & 4.70 & 454.09 & 0.39 \\
\hline$f$ (Control of & & $<0.001$ & $<0.001$ & 0.70 & & $<0.001$ & $<0.001$ & 0.67 & & $<0.001$ & $<0.001$ & 0.70 \\
\hline \multicolumn{13}{|l|}{ corruption) } \\
\hline Adjusted $\mathrm{R}^{2}$ & 0.87 & & & & 0.87 & & & & 0.91 & & & \\
\hline Explained deviance & $90.2 \%$ & & & & $90.1 \%$ & & & & $93.2 \%$ & & & \\
\hline
\end{tabular}




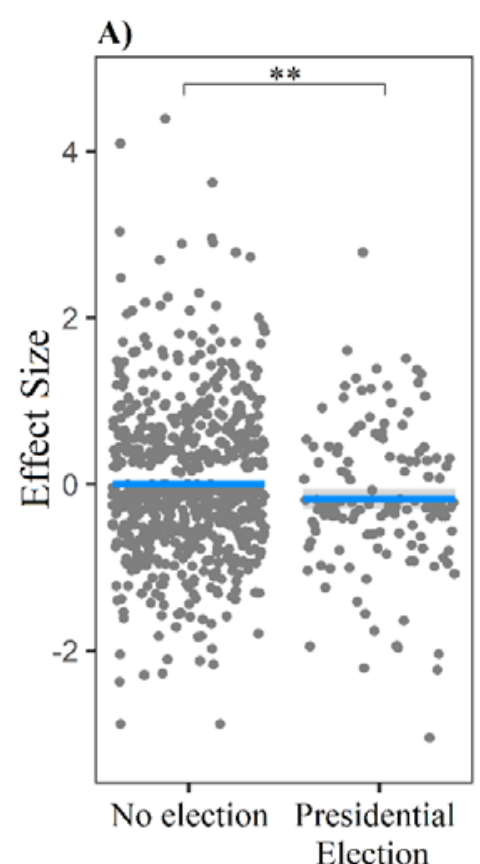

B)

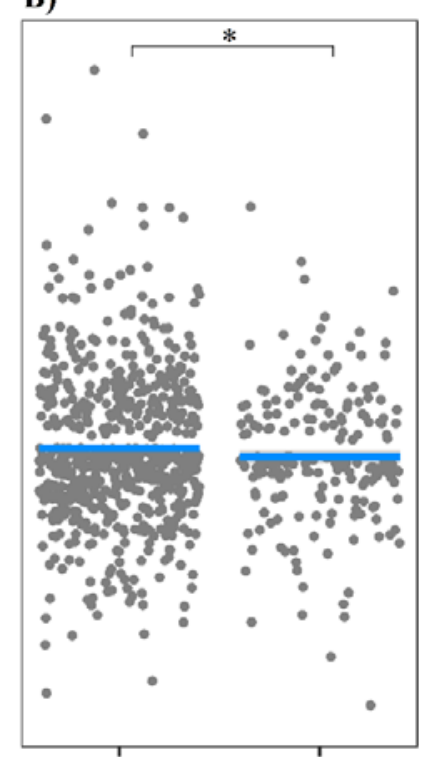

No election Lower chamber
C)

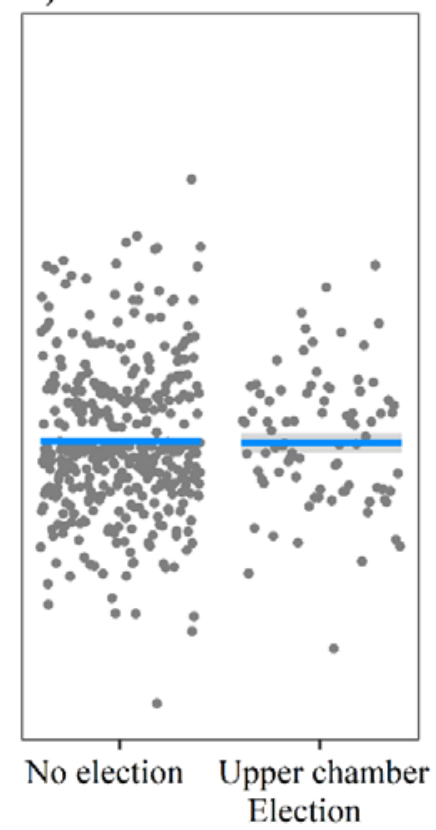

Figure 3. The effect of elections on deforestation. Each point represents the amount of logit-transformed deforestation in a given year and country. The presidential election and lower chamber election ( $A$ and $B$ ) show statistically significant lower deforestation compared to non-election years (compare results for

term in Table 2). Upper chamber elections (C) show a similar but statistically not significant trend.

A)

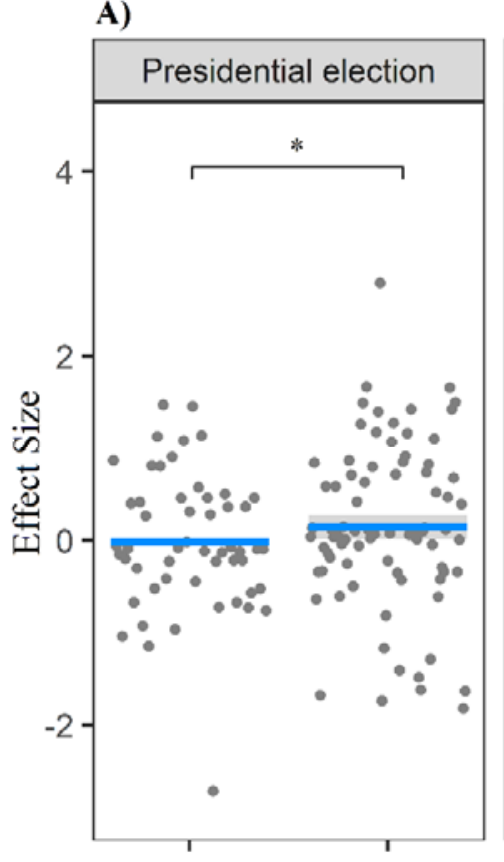

B)

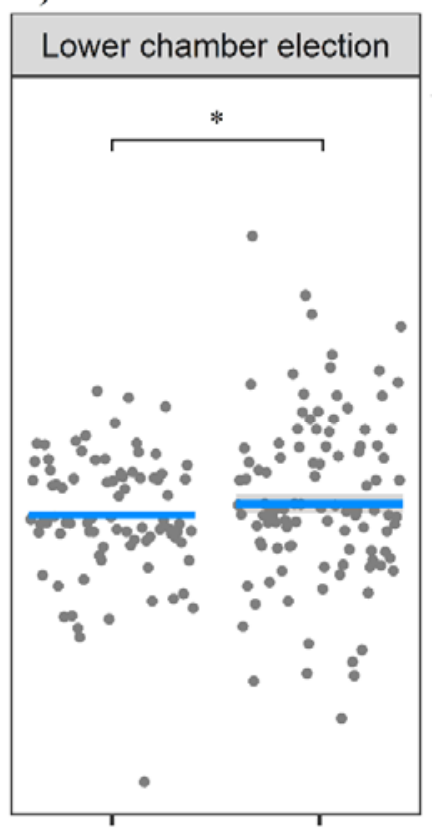

C)

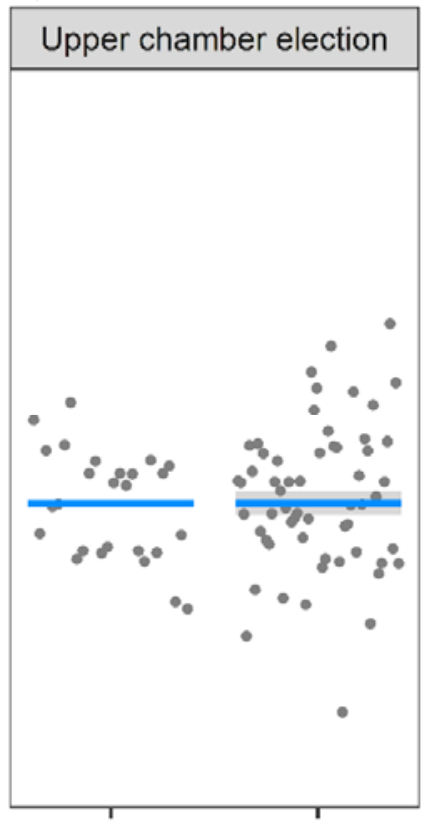

Uncompetitive Competitive

Figure 4. The effect of competitive elections on deforestation. Each point represents the amount of logittransformed deforestation in an election year by country. Competitive presidential and lower chamber elections (A, B) show statistically significant higher deforestation compared to uncompetitive elections (compare results for interaction term in Table 2). Upper chamber elections (C) show an opposite but statistically not significant trend. 


\section{Discussion}

We analysed the effect of elections on deforestation in 55 tropical countries over an 18-year time period and found that competitive elections are potential drivers of pantropical deforestation, whereas a general effect of election years on deforestation was not confirmed. We focused on tropical forests because they are predominantly lost due to agriculture and commodities exploitation rather than changes caused by forestry management and wildfires, as for instance in boreal and taiga forests (Curtis et al., 2018). Our results document a massive tropical forest loss from 2000 to 2018, with the rate of deforestation increasing in more than two-thirds of the studied countries. To our knowledge, this represents the most comprehensive and most up-to-date study of its kind covering a pantropical extent.

Our results confirm the well-known trend that deforestation rates are increasing across the tropics (Curtis et al., 2018). This is alarming since deforestation is accelerating while the remaining forest area is becoming smaller. While the majority of studied countries (70.5\%, HGAM) show linearly or curvilinearly increasing deforestation trends, there are a few countries in which deforestation is decreasing $(13.7 \%)$ or fluctuating with sporadic increases and decreases $(15.6 \%)$. The decreases observed in our results seem to coincide with the implementation of forest protection policies or actions. For example, in 2004, The Brazilian Government founded the country's environmental enforcement agency (IBAMA) which led to a 37\% reduction in deforestation between 2005 and 2007, by using in field enforcement using real time deforestation detection (Arima et al., 2014; Soares-Filho et al., 2010). Similarly, conservation in the Colombian Guyana Shield reduced deforestation in protected area's compared to their buffer zone, with only $1 \%$ of the natural forest in protected areas lost, while the buffer zones lost between 5-7\% between 1985 and 2002. In particular, the reduced deforestation in protected areas was linked with lower infrastructure, accessibility and reduction in illicit agriculture (Armenteras et al., 2009). These examples are encouraging since they show that policy tools and conservation intervention can effectively limit deforestation and that governments have the means to take the necessary steps to halt ongoing deforestation (Busch et al., 2015; Rudorff et al., 2011; Umemiya et al., 2010; Wehkamp et al., 2018).

In contrast to our expectation, we found that deforestation was significantly lower in election years than in non-election years. This is, for instance, opposite to a study at the national scale of Brazil where municipal-level deforestation increased by $8-10 \%$ in years with a municipal election (Pailler 2018). In general, election theory suggests that politicians should utilise all avenues possible to win support and favour in the lead up to an election, which includes giving away or promising forested land for development, or turning a blind eye to forest exploitation (Abessa et al., 
374 2019; Akhmedov and Zhuravskaya, 2003; Burgess et al., 2012; Shi and Svensson, 2006). We suggest 375 that there are several plausible explanations why our analysis did not show such an expected effect.

First, forested land might be exploited before an election, causing an increase in deforestation above baseline levels. This exploitation may then stop shortly after an election, and result in a decrease of deforestation. This has been observed in some countries, for example in Russia, where election cycles in social expenditure from local governments generally drop one month after the election (Akhmedov and Zhuravskaya, 2003). This makes it difficult to detect a signal of elections on deforestation rates when analysing deforestation in yearly intervals since the pre-and post-election increase and decrease could cancel each other out. The global forest loss data that we used is currently only available in yearly intervals (Hansen et al., 2013) and thus does not account for short term pre/post-election changes in deforestation rates (e.g. within years). More detailed data (e.g. capturing intra-annual variation in deforestation rates during election periods) could benefit future studies of forest loss at national and global scales.

A second plausible reason for not detecting an increase of deforestation with presidential, lower and upper chamber elections is that forest governance and natural resource management is increasingly becoming decentralised within countries (Ginsburg and Keene, 2020). In principle, decentralisation should make it more difficult for national level politicians to exploit locally managed resources (Busch and Amarjargal, 2020). It is difficult to account for this decentralisation in global analyses because appropriate data to quantify the degree of local or municipal autonomy in forest management are lacking. Additionally, election data on the subnational administrative units that manage the forests are often missing. Hence, it is possible that local governments protect their forests from exploitation by higher level politicians during national election years. An alternative way to study this could be to investigate the effect of elections on deforestation at the spatial scale at which forest management decision are made. For instance, if forests are managed at the state or county level, the effects of state or county-level elections on deforestation could be analysed. To our knowledge, there are currently no global databases available that specify the level and spatial scale of forest governance.

Besides the general effect of presidential, lower and upper chamber elections on deforestation, our analysis revealed that deforestation is significantly higher in competitive election years compared to non-competitive election years. This supports our expectation that more competitive elections will increase incentives for politicians to misuse public goods for winning favour (Sanford, 2019; Shi and Svensson, 2006). To improve forest protection, we recommend that 
407 Election Monitors (GNDEM) extend their mandate to include monitoring natural resources such as 408 forests (Pereira et al., 2009; Shi and Svensson, 2006). Conservation groups should also remain vigilant 409 during the lead up to elections, especially given land gifting practices for forest exploitation during 410 the elections of Uganda in 2011 (Médard and Golaz, 2013).

\section{5. Conclusions}

412 Protecting biodiversity in tropical forests and their ecosystem services is crucial for meeting 413 international policy targets such as the United Nations Sustainable Development Goals (SDGs) and 414 the post-2020 targets of the Convention on Biological Diversity (CBD). Our analysis shows that 415 tropical forests continue to decline and that elections can at least partly play a role in driving 416 deforestation trends. However, more detailed data on intra-annual variation of deforestation and the 417 spatial scale of forest governance are needed to improve our global (pantropical and cross-national) 418 understanding of how elections influence forest loss driven. We urge electoral management bodies 419 and conservation groups to be vigilant during competitive elections, because forests and other 420 natural resources could be traded for votes. Further elucidating the role of elections on deforestation 421 should be a focus of forest conservation efforts.

422

423 6. Data accessibility

424 Data and code used for this study have been made permanently and publicly available on the 425 Mendeley Data repository at http://dx.doi.org/10.17632/5ngc9n3shd.1. 


\section{Literature}

Abessa, D., Famá, A., Buruaem, L., 2019. The systematic dismantling of Brazilian environmental laws risks losses on all fronts. Nature Ecology \& Evolution 3, 510-511. https://doi.org/10.1038/s41559-019-0855-9

Akhmedov, A., Zhuravskaya, E. V., 2003. Opportunistic political cycles: Test in a young democracy setting. SSRN Electronic Journal 119, 1301-1338. https://doi.org/10.2139/ssrn.396240

Angelsen, A., Jagger, P., Babigumira, R., Belcher, B., Hogarth, N.J., Bauch, S., Börner, J., Smith-Hall, C., Wunder, S., 2014. Environmental income and rural livelihoods: A global-comparative analysis. World Development 64, S12-S28. https://doi.org/10.1016/j.worlddev.2014.03.006

Arima, E.Y., Barreto, P., Araújo, E., Soares-Filho, B., 2014. Public policies can reduce tropical deforestation: Lessons and challenges from Brazil. Land Use Policy 41, 465-473. https://doi.org/10.1016/j.landusepol.2014.06.026

Armenteras, D., Rodríguez, N., Retana, J., 2009. Are conservation strategies effective in avoiding the deforestation of the Colombian Guyana Shield? Biological Conservation 142, 1411-1419. https://doi.org/10.1016/j.biocon.2009.02.002

Austin, K.G., González-Roglich, M., Schaffer-Smith, D., Schwantes, A.M., Swenson, J.J., 2017. Trends in size of tropical deforestation events signal increasing dominance of industrial-scale drivers. Environmental Research Letters 12, 054009. https://doi.org/10.1088/1748-9326/aa6a88

Bertot, J.C., Jaeger, P.T., Grimes, J.M., 2010. Using ICTs to create a culture of transparency: Egovernment and social media as openness and anti-corruption tools for societies. Government Information Quarterly 27, 264-271. https://doi.org/10.1016/j.giq.2010.03.001

Brown, A.R., 2011. Wikipedia as a data source for political scientists: Accuracy and completeness of coverage. PS: Political Science \& Politics 44, 339-343. https://doi.org/10.1017/S1049096511000199

Burgess, R., Hansen, M., Olken, B.A., Potapov, P., Sieber, S., 2012. The political economy of deforestation in the tropics. Quarterly Journal of Economics 127, 1707-1754. https://doi.org/10.1093/qje/qjs034

Busch, J., Amarjargal, O., 2020. Authority of second-tier governments to reduce deforestation in 30 tropical countries. Frontiers in Forests and Global Change 3, 1-14. https://doi.org/10.3389/ffgc.2020.00001

Busch, J., Ferretti-Gallon, K., Engelmann, J., Wright, M., Austin, K.G., Stolle, F., Turubanova, S., Potapov, P. V, Margono, B., Hansen, M.C., Baccini, A., 2015. Reductions in emissions from deforestation from Indonesia's moratorium on new oil palm, timber, and logging concessions. Proceedings of the National Academy of Sciences 112, 1328-1333. https://doi.org/10.1073/pnas.1412514112

Cisneros, E., Kis-Katos, K., Nuryartono, N., 2021. Palm oil and the politics of deforestation in Indonesia. Journal of Environmental Economics and Management 108, 102453. https://doi.org/10.1016/j.jeem.2021.102453

Curtis, P.G., Slay, C.M., Harris, N.L., Tyukavina, A., Hansen, M.C., 2018. Classifying drivers of global forest loss. Science 361, 1108-1111. https://doi.org/10.1126/science.aau3445

Dávalos, L.M., Sanchez, K.M., Armenteras, D., 2016. Deforestation and coca cultivation rooted in twentieth-century development projects. BioScience 66, 974-982.

https://doi.org/10.1093/biosci/biw118 
Douma, J.C., Weedon, J.T., 2019. Analysing continuous proportions in ecology and evolution: A practical introduction to beta and Dirichlet regression. Methods in Ecology and Evolution 10, 1412-1430. https://doi.org/10.1111/2041-210X.13234

Drazen, A., Eslava, M., 2010. Electoral manipulation via voter-friendly spending: Theory and evidence. Journal of Development Economics 92, 39-52. https://doi.org/10.1016/j.jdeveco.2009.01.001

Ewers, R.M., 2006. Interaction effects between economic development and forest cover determine deforestation rates. Global Environmental Change 16, 161-169. https://doi.org/10.1016/j.gloenvcha.2005.12.001

Foley, J.A., Asner, G.P., Heil Costa, M., Coe, M.T., Defries, R., Gibbs, H.K., Howard, E.A., Olson, S., Patz, J., Ramankutty, N., Snyder, P., 2007. Amazonia revealed: forest degradation and loss of ecosystem goods and services in the Amazon Basin. Frontiers in Ecology and the Environment 5 , 25-32. https://doi.org/10.1890/1540-9295(2007)5[25:ARFDAL]2.0.CO;2

Gaston, K.J., 2000. Global patterns in biodiversity. Nature 405, 220-227. https://doi.org/10.1038/35012228

Gibson, L., Lee, T.M., Koh, L.P., Brook, B.W., Gardner, T.A., Barlow, J., Peres, C.A., Bradshaw, C.J.A., Laurance, W.F., Lovejoy, T.E., Sodhi, N.S., 2011. Primary forests are irreplaceable for sustaining tropical biodiversity. Nature 478, 378-381. https://doi.org/10.1038/nature10425

Ginsburg, C., Keene, S., 2020. At a crossroads: Consequential trends in recognition of communitybased forest tenure from 2002-2017. China Economic Journal 13, 223-248. https://doi.org/10.1080/17538963.2020.1755129

Gorelick, N., Hancher, M., Dixon, M., Ilyushchenko, S., Thau, D., Moore, R., 2017. Google Earth Engine: Planetary-scale geospatial analysis for everyone. Remote Sensing of Environment 202, 18-27. https://doi.org/10.1016/j.rse.2017.06.031

Hansen, M.C., Potapov, P. V., Moore, R., Hancher, M., Turubanova, S.A., Tyukavina, A., Thau, D., Stehman, S. V., Goetz, S.J., Loveland, T.R., Kommareddy, A., Egorov, A., Chini, L., Justice, C.O., Townshend, J.R.G., 2013. High-resolution global maps of 21st-century forest cover change. Science 342, 850-853. https://doi.org/10.1126/science.1244693

Heltberg, R., Arndt, T.C., Sekhar, N.U., 2000. Fuelwood consumption and forest degradation: A household model for domestic energy substitution in rural India. Land Economics 76, 213-232. https://doi.org/10.2307/3147225

Hosonuma, N., Herold, M., De Sy, V., De Fries, R.S., Brockhaus, M., Verchot, L., Angelsen, A., Romijn, E., 2012. An assessment of deforestation and forest degradation drivers in developing countries. Environmental Research Letters 7, 044009. https://doi.org/10.1088/17489326/7/4/044009

Joshi, A.K., Joshi, P.K., 2019. Forest ecosystem services in the central Himalaya: Local benefits and global relevance. Proceedings of the National Academy of Sciences, India Section B: Biological Sciences 89, 785-792. https://doi.org/10.1007/s40011-018-0969-x

Kaufmann, D., Kraay, A., Mastruzzi, M., 2011. The worldwide governance indicators: Methodology and analytical issues. Hague Journal on the Rule of Law 3, 220-246. https://doi.org/10.1017/S1876404511200046

Kendall, M.G., 1938. A new measure of rank correlation. Biometrika 30, 81. https://doi.org/10.2307/2332226 
Koh, L.P., Wilcove, D.S., 2008. Is oil palm agriculture really destroying tropical biodiversity? Conservation Letters 1, 60-64. https://doi.org/10.1111/j.1755-263x.2008.00011.x

Kolstad, I., Wiig, A., 2009. Is transparency the key to reducing corruption in resource-rich countries? World Development 37, 521-532. https://doi.org/10.1016/j.worlddev.2008.07.002

Landholm, D.M., Pradhan, P., Kropp, J.P., 2019. Diverging forest land use dynamics induced by armed conflict across the tropics. Global Environmental Change 56, 86-94. https://doi.org/10.1016/j.gloenvcha.2019.03.006

Laurance, W.F., Albernaz, A.K.M., Schroth, G., Fearnside, P.M., Bergen, S., Venticinque, E.M., Da Costa, C. , 2002. Predictors of deforestation in the Brazilian Amazon. Journal of Biogeography 29, 737-748. https://doi.org/10.1046/j.1365-2699.2002.00721.x

Laurance, W.F., Sayer, J., Cassman, K.G., 2014. Agricultural expansion and its impacts on tropical nature. Trends in Ecology \& Evolution 29, 107-116. https://doi.org/10.1016/j.tree.2013.12.001

Lin, X., Zhang, D., 1999. Inference in generalized additive mixed models by using smoothing splines. Journal of the Royal Statistical Society. Series B: Statistical Methodology 61, 381-400. https://doi.org/10.1111/1467-9868.00183

List, J.A., Sturm, D.M., 2006. How elections matter: Theory and evidence from environmental policy. The Quarterly Journal of Economics 121, 1249-1281. https://doi.org/10.1093/qje/121.4.1249

Mann, H.B., 1945. Nonparametric tests against trend. Econometrica 13, 245. https://doi.org/10.2307/1907187

Médard, C., Golaz, V., 2013. Creating dependency: Land and gift-giving practices in Uganda. Journal of Eastern African Studies 7, 549-568. https://doi.org/10.1080/17531055.2013.811027

Negret, P.J., Allan, J., Braczkowski, A., Maron, M., Watson, J.E.M., 2017. Need for conservation planning in postconflict Colombia. Conservation Biology 31, 499-500. https://doi.org/10.1111/cobi.12935

Negret, P.J., Sonter, L., Watson, J.E.M., Possingham, H.P., Jones, K.R., Suarez, C., Ochoa-Quintero, J.M., Maron, M., 2019. Emerging evidence that armed conflict and coca cultivation influence deforestation patterns. Biological Conservation 239, 108176. https://doi.org/10.1016/j.biocon.2019.07.021

Nordhaus, W.D., 1975. The political business cycle. The Review of Economic Studies 42, 169. https://doi.org/10.2307/2296528

Ohman, M., 2013. Controlling money in politics: An introduction, International Foundation for Electoral Systems. Washington.

Pailler, S., 2018. Re-election incentives and deforestation cycles in the Brazilian Amazon. Journal of Environmental Economics and Management 88, 345-365. https://doi.org/10.1016/j.jeem.2018.01.008

Pedersen, E.J., Miller, D.L., Simpson, G.L., Ross, N., 2019. Hierarchical generalized additive models in ecology: An introduction with mgcv. PeerJ 7, e6876. https://doi.org/10.7717/peerj.6876

Pereira, C., Melo, M.A., Figueiredo, C.M., 2009. The corruption-enhancing role of re-election incentives?: Counterintuitive evidence from Brazil's audit reports. Political Research Quarterly 62, 731-744. https://doi.org/10.1177/1065912908320664

Rodrigues-Filho, S., Verburg, R., Bursztyn, M., Lindoso, D., Debortoli, N., Vilhena, A.M.G., 2015. Election-driven weakening of deforestation control in the Brazilian Amazon. Land Use Policy 43, 
111-118. https://doi.org/10.1016/j.landusepol.2014.11.002

Rudorff, B.F.T., Adami, M., Aguiar, D.A., Moreira, M.A., Mello, M.P., Fabiani, L., Amaral, D.F., Pires, B.M., 2011. The soy moratorium in the Amazon biome monitored by remote sensing images. Remote Sensing 3, 185-202. https://doi.org/10.3390/rs3010185

Rudow, A., Rotach, P., Küchli, C., Dürr, C., Schmid, S., Bolliger, M., 2013. The state of the world's forest genetic resources. FAO country report switzerland 2012.

Sandker, M., Finegold, Y., D'Annunzio, R., Lindquist, E., 2017. Global deforestation patterns: Comparing recent and past forest loss processes through a spatially explicit analysis. International Forestry Review 19, 350-368. https://doi.org/10.1505/146554817821865081

Sanford, L., 2019. Supporting Information: Democratization, Elections, and Public Goods: The Evidence from Deforestation.

Shi, M., Svensson, J., 2006. Political budget cycles: Do they differ across countries and why? Journal of Public Economics 90, 1367-1389. https://doi.org/10.1016/j.jpubeco.2005.09.009

Skaaning, S.-E., Gerring, J., Bartusevičius, H., 2015. A lexical index of electoral democracy. Comparative Political Studies 48, 1491-1525. https://doi.org/10.1177/0010414015581050

Smith, J., Obidzinski, K., Subarudi, Suramenggala, I., 2003. Illegal logging, collusive corruption and fragmented governments in Kalimantan, Indonesia. International Forestry Review 5, 293-302. https://doi.org/10.1505/IFOR.5.3.293.19138

Soares-Filho, B., Moutinho, P., Nepstad, D., Anderson, A., Rodrigues, H., Garcia, R., Dietzsch, L., Merry, F., Bowman, M., Hissa, L., Silvestrini, R., Maretti, C., 2010. Role of Brazilian Amazon protected areas in climate change mitigation. Proceedings of the National Academy of Sciences 107, 10821-10826. https://doi.org/10.1073/pnas.0913048107

Tracewski, Ł., Butchart, S.H.M., Donald, P.F., Evans, M., Fishpool, L.D.C., Buchanan, G.M., 2016. Patterns of twenty-first century forest loss across a global network of important sites for biodiversity. Remote Sensing in Ecology and Conservation 2, 37-44. https://doi. org/10.1002/rse2.13

Tropek, R., Sedla ek, O., Beck, J., Keil, P., Musilova, Z., Imova, I., Storch, D., 2014. Comment on "Highresolution global maps of 21st-century forest cover change." Science 344, 981-981. https://doi.org/10.1126/science.1248753

Tufis, C., 2019. The global state of democracy indices codebook, version 3. International Institute for Democracy and Electoral Assistance. https://doi.org/10.31752/idea.2019.40

Umemiya, C., Rametsteiner, E., Kraxner, F., 2010. Quantifying the impacts of the quality of governance on deforestation. Environmental Science and Policy 13, 695-701. https://doi.org/10.1016/j.envsci.2010.07.002

Wehkamp, J., Koch, N., Lübbers, S., Fuss, S., 2018. Governance and deforestation - a meta-analysis in economics. Ecological Economics 144, 214-227. https://doi.org/10.1016/j.ecolecon.2017.07.030

Wood, S.N., 2017. Generalized additive models: An introduction with R, 2nd ed. Chapman and Hall/CRC. https://doi.org/10.1201/9781315370279

Wood, S.N., 2003. Thin plate regression splines. Journal of the Royal Statistical Society: Series B (Statistical Methodology) 65, 95-114. https://doi.org/10.1111/1467-9868.00374

World bank, 2020. World development indicators [WWW Document]. Population density. URL 
https://data.worldbank. org/indicator/EN.POP.DNST (accessed 5.16.20).

603

604

605

606

607

608

609

610

611

612

613

614

615

616

617

618

619

620

621

622

623

624

625

626

627

628

629

630

631

632
Wright, S.J., Sanchez-Azofeifa, G.A., Portillo-Quintero, C., Davies, D., 2007. Poverty and corruption compromise tropical forest reserves. Ecological Applications 17, 1259-1266. https://doi.org/10.1890/06-1330.1

Yue, S., Pilon, P., Cavadias, G., 2002. Power of the Mann-Kendall and Spearman's rho tests for detecting monotonic trends in hydrological series. Journal of Hydrology 259, 254-271. https://doi.org/10.1016/S0022-1694(01)00594-7

\section{Web references}

FEWS (2009), Madagascar admin 2, 2D map Viewed 19 March 2020, < https://fews.net/fewsdata/334?tid=37\&field_data_portal_date_start\%5Bvalue\%5D\%5Byear\%5D=\&field_data_port al_date_start $\% 5$ Bvalue $\% 5 \mathrm{D} \% 5 \mathrm{Bmonth} \% 5 \mathrm{D}=$ \&field_data_portal_date_end\%5Bvalue\%5D\%5B year\% $5 \mathrm{D}=\&$ field_data_portal_date_end $\% 5$ Bvalue $\% 5 \mathrm{D} \% 5 \mathrm{Bm}$ onth $\% 5 \mathrm{D}=>$

FEWS (2016), Mali Admin 1 (2016), 2D map, Viewed 19 March $2020<$ https://fews.net/fewsdata/334?tid=17\&field_data_portal_date_start\%5Bvalue\%5D\%5Byear\%5D=\&field_data_port al_date_start\%5Bvalue\%5D\%5Bmonth\%5D=\&field_data_portal_date_end $\% 5 \mathrm{Bvalue} \% 5 \mathrm{D} \% 5 \mathrm{~B}$ year\%5D=\&field_data_portal_date_end\%5Bvalue\%5D\%5Bmonth\%5D $=>$

GADM, 2018, Spatial data by country, 2D map, Viewed 19 March 2020 https://gadm.org/data.html

Humanitarian Data Exchange (2019), Indonesia - Subnational Administrative Boundaries, 2D map, viewed 21 March $2020<$ https://data.humdata.org/dataset/indonesia-administrativeboundary-polygons-lines-and-places-levels-0-4b>

Humanitarian Data Exchange (2018), United Republic of Tanzania - Subnational Administrative Boundaries, 2D map, Viewed 21 March 2020 https://data.humdata.org/dataset/tanzaniaadministrative-boundaries-level-1-to-3-regions-districts-and-wards-with-2012-population

IPUMS International (2020), YEAR-SPECIFIC FIRST-LEVEL GEOGRAPHY, 2D map, Viewed 21 March 2020 https://international.ipums.org/international/gis yrspecific 1st.shtml

Natural Earth, 2018, Admin 0 - Countries \& Admin 1-States, Provinces. 2D map, Viewed 19 March 2020, < https://www.naturalearthdata.com/downloads/10m-cultural-vectors/10m-admin-1states-provinces/> 